\title{
Analysis of efficiency of photovoltaic bifacial cells
}

\author{
Dariusz Kurz $^{1,{ }^{*}}$, Kamil Lewandowski ${ }^{1}$, and Martyna Szydłowska ${ }^{1}$ \\ ${ }^{1}$ Poznan University of Technology, Faculty of Electrical Engineering, Institute of Electrical Engineering and Electronics, \\ St. Piotrowo 3a, 60 - 965 Poznań, Poland
}

\begin{abstract}
The paper presents the characteristic features and parameters of photovoltaic bifacial cells such as BGE - Bifacial Gain Energy and BR - Bifacial Ratio. Simulation test results of power yields and efficiency from bifacial panels for different values of irradiation and $B G E$ ratio were presented.
\end{abstract}

\section{Introduction}

The improvement of the efficiency of the photovoltaic conversion is one of the major challenges for manufacturers of PV cells. The bifacial cell technology which has been known since the 80's of the previous century has become more and more popular in the recent years, and the manufacturers of photovoltaic panels introduce modern bifacial panels into the market $[1,2]$.

The bifacial technology allows for the conversion of direct sunlight, which reaches the front part of the panel, and the radiation reflected from the surface and dispersed, reaching the back side of the panel. Panels manufactured in this technology may be installed on the ground, flat roofs, mast or solar tracking systems. The provision of optimal conditions for the operation of cells and the proper estimation of the real energy yield from the bifacial installation is necessary for the proper selection of energy storages [3-6].

The basic parameters which define the bifacial cells include $[2,7,8]$ :

- $\quad \boldsymbol{B} \boldsymbol{G E}[\%]$ (Bifacial Gain Energy) - the ratio which expresses the additional energy generated by the rear part of the module, referred to the energy generated from its upper part:

$$
B G E=(\text { Rear/Front })
$$

where:

Rear - the measured energy generated from the rear surface of the module (measured in standard test conditions without the participation of the front part) [kWh],

Front - the measured energy generated from the front surface of the module (measured in standard test conditions without the participation of the rear part) [kWh],

- BR [\%] (Bifacial Ratio) - the ratio which expresses the relationship between the nominal power of the rear part of the module (obtained in standard test conditions) to the power of the front part:

where:

$$
B R=100 \cdot\left(P_{R} / P_{F}\right)
$$

$P_{R}$ - the nominal power of the rear part of the module received in standard test conditions [W],

$P_{F}$ - the nominal power of the front part of the module received in standard test conditions [W].

\section{Tests and simulations of bifacial cells}

In literature on this subject, it is possible to find many publications regarding the bifacial cell testing, depending on many variables such as e.g. the height of the panel installation, the angle of inclination, the surface reflection coefficient, the latitude, the deviation from the south, etc. [2,8-10]. Figure 1 presents the tests conducted by the authors of the paper [2] in the year 2014, in the U.S., using three Canadian Solar CS6P-245M monofacial panels and 2 Prism Solar B245 bifacial panels installed at the height of $0.2 \mathrm{~m}$, inclined at an angle of $20^{\circ}$ to the surface with the albedo (reflection coefficient) equal to $70 \%$.

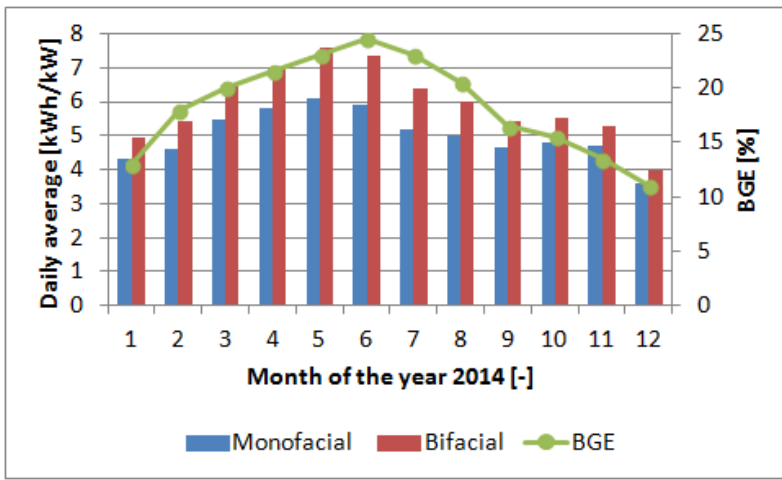

Fig. 1. Average daily energy yields and BGE, obtained in the tests conducted by the authors of the paper [2].

The panels selected for the comparison have the identical rated power in STC conditions, however, in view of the high albedo of the surface, the installation comprising bifacial panels during the best measuring day in June generated almost $25 \%$ more of the energy in comparison to the traditional models. The lowest values

Corresponding author: dariusz.kurz@put.poznan.pl 
of $B G E$ were observed during the winter season, however its daily average value is higher than $10 \%$.

The simulations of power yields from LG NeON2 BiFacial LG300N1T-G4 bifacial panels were performed using the Matlab/Simulink software [11], for different values of the $B G E$ at the constant value of irradiation $E$ (table 1 and fig. 2) and for variable values of $B G E$ and $E$ (table 1 and fig. 3). Descriptions of the current-voltage curves and power curves for different simulation conditions (presented in fig. 2 and fig. 3) are included in table 1 . Based on the presented results, it is possible to notice the linear relationship between the values of the current generated by the panel and the irradiation, which is the sum of currents generated from the front and rear parts of the panel. The value of efficiency of the photovoltaic conversion increases by more than $33 \%$ (for $B G E=30 \%$ as compared to the monofacial cells, at $E=1000 \mathrm{~W} / \mathrm{m}^{2}$ ).

Table 1. Simulation parameters for the LG NeON2 BiFacial LG300N1T-G4 panel.

\begin{tabular}{|c|c|c|c|c|c|c|c|c|}
\hline & \multicolumn{8}{|c|}{$\mathbf{E}\left[\mathbf{W} / \mathbf{m}^{2}\right]$} \\
\hline & \multicolumn{4}{|c|}{1000} & \multicolumn{2}{|c|}{700} & \multicolumn{2}{|c|}{300} \\
\hline & \multicolumn{8}{|c|}{ BGE [\%] } \\
\hline & 0 & 10 & 20 & 30 & 0 & 20 & 0 & 20 \\
\hline Curve on fig. 2 and fig. 3 & $\mathbf{A}$ & B & $\mathbf{C}$ & D & $\mathbf{E}$ & $\mathbf{F}$ & $\mathbf{G}$ & $\mathbf{H}$ \\
\hline $\mathrm{P}_{\max }[\mathrm{W}]$ & 284,57 & 318,34 & 347,21 & 379,78 & 198,23 & 241,43 & 82,09 & 99,70 \\
\hline $\mathrm{I}_{\mathrm{MPP}}[\mathrm{A}]$ & 8,95 & 9,92 & 10,82 & 11,75 & 6,27 & 7,58 & 2,69 & 3,25 \\
\hline $\mathrm{U}_{\mathrm{MPP}}[\mathrm{V}]$ & 31,79 & 32,09 & 32,09 & 32,33 & 31,61 & 31,85 & 30,53 & 30,71 \\
\hline $\mathrm{I}_{\mathrm{SC}}[\mathrm{A}]$ & 9,65 & 10,68 & 11,65 & 12,64 & 6,76 & 8,16 & 2,90 & 3,50 \\
\hline $\mathrm{U}_{\mathrm{OC}}[\mathrm{V}]$ & 40,01 & 40,13 & 40,19 & 40,37 & 39,23 & 39,35 & 37,25 & 37,37 \\
\hline$\eta[\%]$ & 17,35 & 19,41 & 21,17 & 23,16 & 12,09 & 14,72 & 5,01 & 6,08 \\
\hline
\end{tabular}

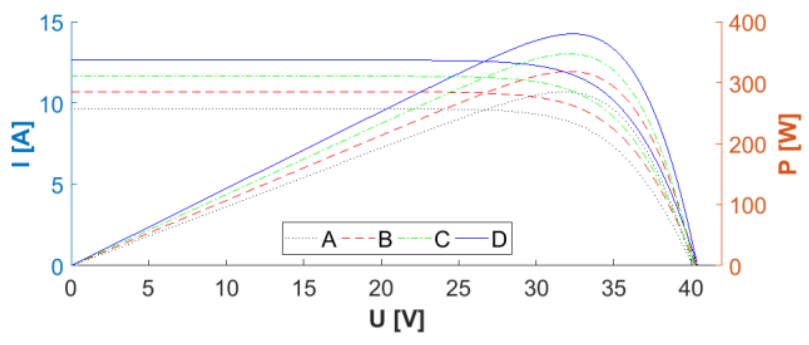

Fig. 2. Current-voltage characteristics and power characteristics of the LG300N1T-G4 bifacial panel for different $B G E$ values.

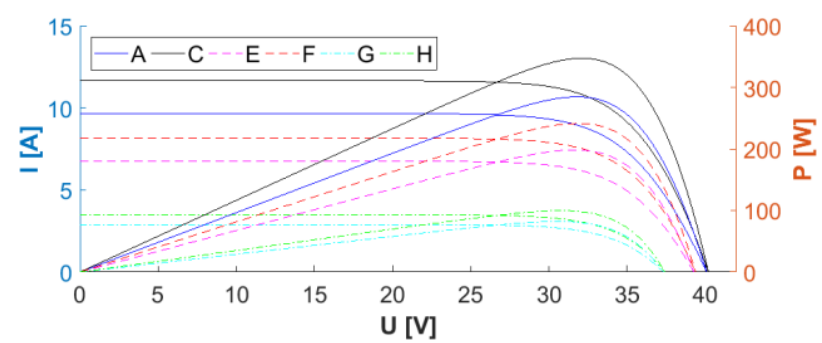

Fig. 3. Current-voltage characteristics and power characteristics of the LG300N1T-G4 bifacial panel for different $B G E$ and $E$ values.

\section{Conclusions}

The presented test results and the performed simulations indicate the possibility of obtaining additional energy, by means of photovoltaic bifacial modules in comparison with the monofacial ones. There are relationships between the parameters of the bifacial installation and the annual additional energy yield from a bifacial module. The main parameters which affect the value of $B G E$ are: the surface reflection coefficient, i.e. albedo, the angle of inclination of the modules in relation to the surface and the height of the installation.
The use of bifacial cells may reduce the investment costs for PV installations and decrease the demand for the installation surface in view of the achieved higher energy yields as compared to the traditional one-sided PV panels, even up to $15-20 \%$ per year.

\section{References}

1. A. Cuevas, A. Luque, J. Eguren, J. D. Alamo, Solar Cells 3/4, 337 (1981)

2. J. E. Castillo-Aguilella, P. S. Hauser, IEEE Access 4, 498 (2016)

3. G. Frydrychowicz - Jastrzębska, A. Bugała, Energies 8, 1025 (2015)

4. G. Trzmiel, Eksploat. Niezawodn. 19/4, 516 (2017)

5. A. Bugała, K. Bednarek, L. Kasprzyk, A. Tomczewski, International Conference EEMS Energy, Environment and Material Systems, (EEMS, E3S Web of Conferences 19, 01002, 2017)

6. D. Głuchy, L. Kasprzyk, Prz. Elektrotech. 93, 99 (2017)

7. C. Deline, S. MacAlpine, B. Marion, F. Toor, A. Asgharzadeh, J. S. Stein, IEEE Journal of Photovoltaics 7/2, 575 (2017)

8. D. Kurz, K. Lewandowski, M. Szydłowska, Pozn. Univ. Technol. Acad. J. Electr. Eng. 94, 215 (2018)

9. C. Erben, J. B. Heng, Z. Xie, J. Fatehi, B. Yang, $42^{r d}$ IEEE Photovoltaic Specialists Conference, (PVSC, 1-3, 2015)

10. L. Kreinin, A. Karsenty, D. Grobgeld, N. Eisenberg, $43^{\text {rd }}$ IEEE Photovoltaic Specialists Conference, (PVSC, 2688-2691, 2016)

11. LG300N1T-G4 panel data sheet: http://www.lgsolar.com/downloads/products/LGE-Data\%20SheetLG300N1T-G4-EN-08.2016.pdf, access: 04.06.2018 